\title{
ANALYSIS OF p-n JUNCTION BOUNDARY CONDITIONS AT HIGH-LEVEL INJECTION OF MINORITY CARRIERS
}

\author{
A. Baškys \\ Faculty of Electronics, Vilnius Gediminas Technical University, Naugarduko 41, LT-03227 Vilnius, Lithuania \\ E-mail: algirdas.baskys@vgtu.lt
}

Received 18 November 2013; accepted 4 December 2013

\begin{abstract}
The equations of boundary conditions of the junction, which can be an alternative to the commonly used exponential equations, are proposed. The derived equations take into account the main event that arises at the high-level injection - dependence of majority carrier boundary concentrations on voltage drop across the depletion region that is essential for the p-n junctions of the present-day semiconductor devices, but is not reflected in the exponential equations of boundary conditions.
\end{abstract}

Keywords: $\mathrm{p}-\mathrm{n}$ junction, boundary conditions, high-level injection, analytic model, electronic circuits simulation

PACS: 85.30.De, 85.30.Kk

\section{Introduction}

The p-n junction is still the basic building block of many semiconductor devices. Because of this, the equation of voltage-current $(v-i)$ characteristic of the $\mathrm{p}-\mathrm{n}$ junction depletion region remains important in creating analytic models for simulation of electronic circuits and understanding the operation of semiconductor devices. The basis for derivation of the equation of the depletion region $v-i$ characteristic are the boundary conditions which present the equations that relate the boundary concentrations of minority carriers at the edges of the depletion region and the voltage drop across the depletion region $\left(U_{\mathrm{d}}\right)$ and is central to the $\mathrm{p}-\mathrm{n}$ junction theory. The present-day analytic models of the semiconductor devices used for simulation of electronic circuits [1-3] and for educational purposes [4-6] are based on the exponential equation of the depletion region $v-i$ characteristic obtained using the exponential equations of boundary conditions of the junction [ [7]. However, there is a well known contradiction between the theory that offers exponential equations of boundary conditions of the $p-n$ junction and the present-day reality. The problem is that current density of junctions, especially of those that are used in power semiconductor devices and in high-speed integrated circuits, has increased strongly since the exponential equations of boundary conditions of the junction were introduced and, as a consequence, the validity of some assumptions used during the derivation of these equations is violated in recent semiconductor devices. It is obvi- ous that it is impossible to obtain analytic equations of boundary conditions of the junction in explicit form, which would take into account most events caused by the high current density; however, some improvement of exponential equations is possible.

The only difference of derivation procedure of equations of boundary conditions of the junction proposed in this work as compared to the classical procedure is that derivation is carried out considering the dependence of the boundary concentrations of majority carriers on $U_{\mathrm{d}}$, which is essential at increased current density. This improvement allows us to obtain more general equations of boundary conditions of the junction as compared to the exponential equations. The derivation is carried out on the basis of the universally accepted Boltzmann relations and charge quasi-neutrality conditions that are acceptable at relatively high current density [3, 8, 9]. The equations are obtained assuming that the junction is one-dimensional, abrupt, and homogeneously doped.

\section{Derivation of equations of boundary conditions of the junction}

Using Boltzmann relations

$$
\begin{aligned}
& p_{\mathrm{n}}\left(x_{\mathrm{n}}\right)=p_{\mathrm{p}}\left(-x_{\mathrm{p}}\right) \exp \left(-\frac{V_{\mathrm{B}}-U_{\mathrm{d}}}{V_{\mathrm{T}}}\right), \\
& n_{\mathrm{p}}\left(-x_{\mathrm{p}}\right)=n_{\mathrm{n}}\left(x_{\mathrm{n}}\right) \exp \left(-\frac{V_{\mathrm{B}}-U_{\mathrm{d}}}{V_{\mathrm{T}}}\right),
\end{aligned}
$$

and charge quasi-neutrality conditions 


$$
\begin{aligned}
& p_{\mathrm{p}}\left(-x_{\mathrm{p}}\right)=N_{\mathrm{A}}+n_{\mathrm{p}}\left(-x_{\mathrm{p}}\right), \\
& n_{\mathrm{n}}\left(x_{\mathrm{n}}\right)=N_{\mathrm{D}}+p_{\mathrm{n}}\left(x_{\mathrm{n}}\right),
\end{aligned}
$$

the following system of equations can be derived:

$$
\left\{\begin{array}{l}
p_{\mathrm{n}}\left(x_{\mathrm{n}}\right)=n_{\mathrm{p}}\left(-x_{\mathrm{p}}\right) \exp \left(-\frac{V_{\mathrm{B}}-U_{\mathrm{d}}}{V_{\mathrm{T}}}\right)-N_{D} \\
n_{\mathrm{p}}\left(-x_{\mathrm{p}}\right)=p_{\mathrm{n}}\left(x_{\mathrm{n}}\right) \exp \left(\frac{V_{\mathrm{B}}-U_{\mathrm{d}}}{V_{\mathrm{T}}}\right)-N_{A}
\end{array}\right.
$$

and solved in terms of $p_{\mathrm{n}}\left(x_{\mathrm{n}}\right)$ and $n_{\mathrm{p}}\left(-x_{\mathrm{p}}\right)$ :

$$
\begin{gathered}
p_{\mathrm{n}}\left(x_{\mathrm{n}}\right)=\frac{N_{\mathrm{A}} \exp \left(\frac{V_{\mathrm{B}}-U_{\mathrm{d}}}{V_{\mathrm{T}}}\right)+N_{\mathrm{D}}}{\exp \left(2 \frac{V_{\mathrm{B}}-U_{\mathrm{d}}}{V_{\mathrm{T}}}\right)-1}, \\
n_{\mathrm{p}}\left(-x_{\mathrm{p}}\right)=\frac{N_{\mathrm{D}} \exp \left(\frac{V_{\mathrm{B}}-U_{\mathrm{d}}}{V_{\mathrm{T}}}\right)+N_{\mathrm{A}}}{\exp \left(2 \frac{V_{\mathrm{B}}-U_{\mathrm{d}}}{V_{\mathrm{T}}}\right)-1},
\end{gathered}
$$

where $p_{\mathrm{n}}\left(x_{\mathrm{n}}\right), n_{\mathrm{p}}\left(-x_{\mathrm{p}}\right)$ are hole and electron (minority carrier) boundary concentrations and $n_{\mathrm{n}}\left(x_{\mathrm{n}}\right), p_{\mathrm{p}}\left(-x_{\mathrm{p}}\right)$ are electron and hole (majority carrier) boundary concentrations at the edges of the depletion region $x=x_{\mathrm{n}}$, and $x=-x_{\mathrm{p}}$ at given voltage $U_{\mathrm{d}}, N_{\mathrm{A}}$ and $N_{\mathrm{D}}$ are impurity (acceptor and donor) concentrations, $V_{\mathrm{T}}$ is the thermal voltage, and $V_{\mathrm{B}}$ is the potential barrier of the junction.

It should be noted that the p-n junction is typically analysed assuming that the whole applied voltage appears across the depletion region. Because of this, in most books dedicated to physics of semiconductor devices the voltage $U_{\mathrm{d}}$ in the equations of boundary conditions of the junction is called the applied voltage.

Using Eqs. (1) at $U_{\mathrm{d}}=0$ and taking into account the fact that for actual junctions $\exp \left[2\left(V_{\mathrm{B}} / V_{\mathrm{T}}\right)\right]>>1$ and $\exp \left(V_{\mathrm{B}} / V_{\mathrm{T}}\right)>>N_{\mathrm{A}} / N_{\mathrm{D}}, N_{\mathrm{D}} / N_{\mathrm{A}}$, the impurity concentrations $N_{\mathrm{A}}$ and $N_{\mathrm{D}}$ can be expressed in terms of minority carrier concentrations at the equilibrium state $\left(U_{\mathrm{d}}=0\right)$ $n_{\mathrm{p} 0}$ and $p_{\mathrm{n} 0}$. Substituting these expressions into Eqs. (4), the following equations of boundary concentrations of minority carriers are obtained:

$$
\begin{aligned}
& p_{\mathrm{n}}\left(x_{\mathrm{n}}\right)=p_{\mathrm{n} 0} \exp \left(\frac{U_{\mathrm{d}}}{V_{\mathrm{T}}}\right) \frac{1+\frac{n_{\mathrm{p} 0}}{p_{\mathrm{n} 0}} \exp \left(-\frac{V_{\mathrm{B}}-U_{\mathrm{d}}}{V_{\mathrm{T}}}\right)}{1-\exp \left(-2 \frac{V_{\mathrm{B}}-U_{\mathrm{d}}}{V_{\mathrm{T}}}\right)}, \\
& n_{\mathrm{p}}\left(-x_{\mathrm{p}}\right)=n_{\mathrm{p} 0} \exp \left(\frac{U_{\mathrm{d}}}{V_{\mathrm{T}}}\right) \frac{1+\frac{p_{\mathrm{n} 0}}{n_{\mathrm{p} 0}} \exp \left(-\frac{V_{\mathrm{B}}-U_{\mathrm{d}}}{V_{\mathrm{T}}}\right)}{1-\exp \left(-2 \frac{V_{\mathrm{B}}-U_{\mathrm{d}}}{V_{\mathrm{T}}}\right)} .
\end{aligned}
$$

Equations (5) are the equations of boundary conditions of the junction considering the dependence of the boundary concentrations of majority carriers on $U_{\mathrm{d}}$. The only difference of the derivation procedure of Eqs. (5) as compared to the classical procedure, which leads to the exponential equations, is that simplifying assumptions $p_{\mathrm{p}}\left(-x_{\mathrm{p}}\right)=N_{\mathrm{A}}$ and $n_{\mathrm{n}}\left(x_{\mathrm{n}}\right)=N_{\mathrm{D}}$ used in the classical procedure were rejected, i. e. the means that allow us to analyse how the dependence of $p_{\mathrm{p}}\left(-x_{\mathrm{p}}\right)$ and $n_{\mathrm{n}}\left(x_{\mathrm{n}}\right)$ on $U_{\mathrm{d}}$ affects the boundary conditions of the junction were not removed. It is necessary to stress that the validity of derived equations of boundary conditions of the junction (5) is limited by the validity of the Boltzmann relations (1) and charge quasi-neutrality conditions (2).

If the junction is symmetric, i. e. $n_{\mathrm{p} 0}=p_{\mathrm{n} 0}$, Eqs. (5) simplify to

$$
\begin{aligned}
& p_{\mathrm{n}}\left(x_{\mathrm{n}}\right)=p_{\mathrm{n} 0} \frac{\exp \left(\frac{U_{\mathrm{d}}}{V_{\mathrm{T}}}\right)}{1-\exp \left(-\frac{V_{\mathrm{B}}-U_{\mathrm{d}}}{V_{\mathrm{T}}}\right)}, \\
& n_{\mathrm{p}}\left(-x_{\mathrm{p}}\right)=n_{\mathrm{p} 0} \frac{\exp \left(\frac{U_{\mathrm{d}}}{V_{\mathrm{T}}}\right)}{1-\exp \left(-\frac{V_{\mathrm{B}}-U_{\mathrm{d}}}{V_{\mathrm{T}}}\right)} .
\end{aligned}
$$

It is seen that the exponential equations of boundary conditions of the junction is a specific case of (5) and (6) at low $U_{\mathrm{d}}$ (at $U_{\mathrm{d}}<V_{\mathrm{B}}-$ several $V_{\mathrm{T}}$ ). For example, Eqs. (6) coincide with the exponential equations when $\exp \left[-\left(V_{\mathrm{B}}-U_{\mathrm{d}}\right) / V_{\mathrm{T}}\right]<<1$. Assuming that this condition is valid when $\exp \left[-\left(V_{\mathrm{B}}-U_{\mathrm{d}}\right) / V_{\mathrm{T}}\right]<0.01$, the $U_{\mathrm{d}}$ can be considered low for the symmetric junction if it meets the requirement $U_{\mathrm{d}}<V_{\mathrm{B}}-4.6 V_{\mathrm{T}}$. In case of the asymmetric junction, the threshold value of $U_{\mathrm{d}}$, starting from which $U_{\mathrm{d}}$ can be considered low, is different for holes and electrons (5) and is dependent on the ratio of impurity concentrations because $n_{\mathrm{p} 0} / p_{\mathrm{n} 0}=N_{\mathrm{D}} / N_{\mathrm{A}}$.

Equations (5) take into account the occurrences of the depletion region that emerge at high $U_{\mathrm{d}}$ (at $V_{\mathrm{B}}$ - several $V_{\mathrm{T}}<U_{\mathrm{d}}<V_{\mathrm{B}}$ ) and are not reflected in the equations of the exponential boundary conditions of the junction. These occurrences are:

(i) the increased steepness of $p_{n}\left(x_{n}\right)$ and $n_{p}\left(-x_{p}\right)$ dependences on $U_{\mathrm{d}}$ as compared to the exponential boundary conditions;

(ii) the limitation of the $U_{\mathrm{d}}$ value by the $V_{\mathrm{B}}$ value;

(iii) the decrease of the asymmetry of the asymmetric p-n junction.

These occurrences, which are not widely discussed in the literature dedicated to semiconductor devices, can be explained by the fact that at high $U_{\mathrm{d}}$ the 
boundary concentrations of majority carriers $p_{\mathrm{p}}\left(-x_{\mathrm{p}}\right)$ and $n_{\mathrm{n}}\left(x_{\mathrm{n}}\right)$ become dependent on $U_{\mathrm{d}}$. Because of this, the injection is provided from the regions with the variable concentration of majority carriers. Since $p_{\mathrm{p}}\left(-x_{\mathrm{p}}\right)$ and $n_{\mathrm{n}}\left(x_{\mathrm{n}}\right)$ increase when $U_{\mathrm{d}}$ increases, the law of the dependence becomes more steep as compared to the exponential law. The appreciable change of boundary concentrations of majority carriers in the lower doped region starts at lower $U_{\mathrm{d}}$; therefore, first of all the law of the dependence fails to agree with the exponential law for the minority carriers injected into the higher doped region when $U_{\mathrm{d}}$ increases.

The concentration of minority carriers injected into the lower doped side is higher as compared to that injected into the higher doped side. Because of this, the rise of $U_{\mathrm{d}}$ lowers the asymmetry of the junction and, what is more, at high $U_{\mathrm{d}}$ the $p_{\mathrm{p}}\left(-x_{\mathrm{p}}\right)$ and $n_{\mathrm{n}}\left(x_{\mathrm{n}}\right)$ in the asymmetric junction may become comparable.

The proposed equations of boundary conditions of the junction (5) were used for the derivation of equations of the $\mathrm{p}-\mathrm{n}$ junction carrier injection level [10]. The equation of $v-i$ characteristic of the p-n junction depletion region obtained on the basis of (5) was employed for analytic analysis of integrated circuits based on the differential amplifiers [11, 12].

It is obvious that any analytic model is an approximation which takes into account more or fewer facts of a real device. The derived equations of boundary conditions of the junction (5) and (6) include occurrences that are essential for the $\mathrm{p}$-n junctions of the present-day semiconductor devices. However, they do not take into consideration such effects as dependence of $V_{\mathrm{B}}$ on $U_{\mathrm{d}}$ or electron-hole scattering that come into play at high $U_{\mathrm{d}}$. The reason is that inclusion of these effects eliminates the possibility to obtain the equations of boundary conditions of the junction in explicit form. On the other hand, the exponential equations of the boundary conditions of the junction do not include any factor that arises at high $U_{\mathrm{d}}$, but in spite of this they are the basis of present-day analytic electric models of semiconductor devices used for simulation of electric circuits and are the only equations of the boundary conditions of the junction used for training the $p-n$ junction operation.

The main purpose of this work was to derive the equations that could be an alternative to the exponential equations of boundary conditions of the junction. Therefore, it is of interest to discuss and analyse them from this point of view.

\section{Analysis of concrete p-n junctions}

To examine the derived equations of boundary conditions of the junction, an asymmetric $\left(N_{\mathrm{A}}=10^{17} \mathrm{~cm}^{-3}\right.$,
$N_{\mathrm{D}}=10^{15} \mathrm{~cm}^{-3}$ ) silicon $\mathrm{p}-\mathrm{n}$ junction was analysed. The analysis was performed at room temperature assuming that junctions are abrupt and homogeneously doped. Using widely known relations $V_{\mathrm{B}}=V_{\mathrm{T}} \ln \left[N_{\mathrm{A}} N_{\mathrm{D}} /\right.$ $\left.n_{\mathrm{i}}^{2}\right], p_{\mathrm{n} 0}=n_{\mathrm{i}}^{2} / N_{\mathrm{D}}$ and $n_{\mathrm{p} 0}=n_{\mathrm{i}}^{2} / N_{\mathrm{A}}\left(n_{\mathrm{i}}\right.$ is intrinsic carrier concentration), the dependences of $p_{n}\left(x_{n}\right)$ and $n_{\mathrm{p}}\left(-x_{\mathrm{p}}\right)$ on $U_{d}$ on the basis of the exponential equations and Eqs. (5) were computed (Fig.11).

It is seen (Fig. 1) that at low $U_{d}$ the dependences calculated using exponential equations and Eqs. (5) coincide. When $U_{\mathrm{d}}$ becomes high and increases, Eqs. (5) give a higher rise of minority carrier concentrations as compared to the exponential law. The values of $p_{\mathrm{n}}\left(x_{\mathrm{n}}\right)$ and $n_{\mathrm{p}}\left(-x_{\mathrm{p}}\right)$ calculated using (5) fail to agree with the result obtained using exponential equations at different $U_{d}$ (Fig. 1). This disagreement starts at lower $U_{d}$ for $n_{\mathrm{p}}\left(-x_{\mathrm{p}}\right)$, i. e. for the minority carriers injected into the higher doped region.

Furthermore, the dependences obtained on the basis of Eqs. (5) show that in the asymmetric p-n junction, when $U_{\mathrm{d}}$ is close to $V_{\mathrm{B}}$, the values of $p_{\mathrm{n}}\left(x_{\mathrm{n}}\right)$ and $n_{p}\left(-x_{p}\right)$ may become comparable (solid lines in figure).

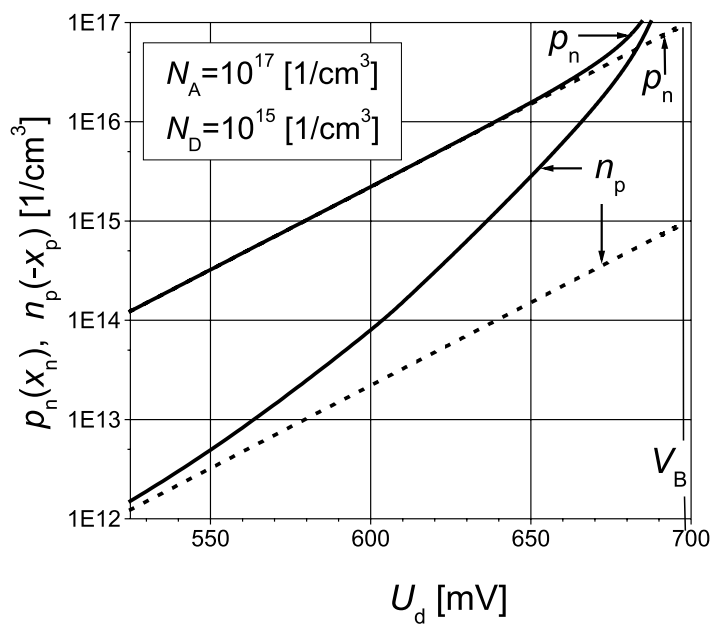

Fig. 1. Dependences of minority carrier boundary concentrations on the voltage drop across the depletion region for asymmetric silicon junction calculated using equations of boundary conditions of the junction (5) (solid lines) and exponential equations (dashed lines).

\section{Conclusions}

1. The derived equations of boundary conditions of the junction are an alternative to the commonly used exponential equations.

2. The obtained Eqs. (5) take into account the following occurrences that emerge at high $U_{\mathrm{d}}$ and are not 
reflected in the equations of the exponential boundary conditions of the junction:

(i) the increased steepness of $p_{n}\left(x_{n}\right)$ and $n_{p}\left(-x_{p}\right)$ dependences on $U_{\mathrm{d}}$ as compared to the exponential law;

(ii) the limitation of the $U_{\mathrm{d}}$ value by the $V_{\mathrm{B}}$ value;

(iii) the decrease of the asymmetry of the asymmetric $\mathrm{p}-\mathrm{n}$ junction.

3. The validity of derived equations of boundary conditions of the junction is limited by the validity of the Boltzmann relations and charge quasi-neutrality conditions.

\section{Acknowledgements}

This work was supported partly by the Agency for Science, Innovation and Technology (MITA) under project 31V-37 (2012), 31V-35 (2013).

\section{References}

[1] M. Schroter, S. Lehmann, S. Fregonese, and T. Zimmer, A computationally efficient physics-based compact bipolar transistor model for circuit design - part I: model formulation, IEEE Trans. Electron Dev. 53(2), 279-286 (2006).

[2] S. Fregonese, S. Lehmann, T. Zimmer, M. Schroter, D. Celi, B. Ardouin, H. Beckrich, P. Brenner, and W. Kraus, A computationally efficient physicsbased compact bipolar transistor model for circuit design - part II: parameter extraction and experimental results, IEEE Trans. Electron Dev. 53(2), 287-295 (2006).
[3] G. Massobrio and P. Antognetti, Semiconductor Device Modeling with SPICE (McGraw-Hill, New York, 1993).

[4] R.F. Pierret, Semiconductor Device Fundamentals (Addison-Wesley Publishing Company, New York, 1996).

[5] M.N. Horenstein, Microelectronic Circuits and Devices (Prentice-Hall, Englewood Cliffs, 1996).

[6] S.Štaras, Fundamentals of Electronics: Semiconductor Device Physics (Technika, Vilnius, 1999).

[7] H.R. Pota, A new derivation of the law of the junctions, IEEE Trans. Educ. 47(4), 497-499 (2004).

[8] T.T. Mnatskanov, D. Schroder, and A.E. Schlogl, Effect of high injection level phenomena on the feasibility of diffusive approximation in semiconductor device modeling, Solid State Electron. 42(1), 153-163 (1998).

[9] R.S. Muller and T.I. Kamins, Device Electronics for Integrated Circuits (John Wiley and Sons, New York, 1986).

[10]A. Baskys, M. Sapurov, and R. Zubavicius, The new equations of $\mathrm{p}-\mathrm{n}$ junction carrier injection level, Elektronika ir elektrotechnika (Electronics and Electrical Engineering) 19(2), 45-48 (2013).

[11]A. Baskys, L. Nickelson, and R. Navickas, Analytical method for differential amplifier offset voltage analysis, Elektronika ir elektrotechnika (Electronics and Electrical Engineering) 108(2), 51-54 (2011).

[12] A. Baskys, R. Navickas, and C. Simkevicius, The fast differential amplifier-based integrated circuit yield analysis technique, Acta Phys. Pol. A 119(2), 259-261 (2011).

\title{
p-n SANDŪROS KRAŠTINIŲ SĄLYGŲ ANALIZĖ DIDELĖS ŠALUTINIŲ KRÜVININKỤ INJEKCIJOS REŽIME
}

\author{
A. Baškys \\ Vilniaus Gedimino technikos universitetas, Elektronikos fakultetas, Vilnius, Lietuva
}

\begin{abstract}
Santrauka
Pasiūlytos p-n sandūros ribinių sąlygų išraiškos, kurios yra alternatyva plačiai naudojamoms eksponentinèms išraiškoms. Ivertintas pagrindinis reiškinys, pasireiškiantis esant aukštai šalutinių krūvininkų injekcijai - pagrindinių krūvininkų tankio priklausomybė nuo
\end{abstract}

itampos kritimo nuskurdintame sluoksnyje. Tai aktualu šiuolaikinių puslaidininkinių prietaisų sandūroms, tačiau nèra ịvertinama eksponentinèse sandūros ribinių sąlygų išraiškose. Pasiūlytos išraiškos gali būti pritaikytos kuriant naujus analitinius puslaidininkinių prietaisų elektrinius modelius elektroninių schemų modeliavimui. 